the film after 12-16 hr. exposure (see Fig. 1). About five hundred mosquitoes can be mounted on the 8 in. $\times 10$ in. standard film, and it is suggested that this simple method of detection of labelled insects might be of value for qualitative ecological studies, such as investigation of the range of flight. This is of particular interest in tropical areas where electronic equipment is not available in field conditions.

L. J. BRUCE-ChWATT Malaria Service, Department of Botany
Unt J. HAYWARD Nigeria. Isotope School, Swansea.

Atomic Energy Research Establishment, Harwell, Berks. Nov. 5.

\section{Nutritional Aspects of Mortierella hygrophila Linn.}

Physiologrcal studies on micro-organisms regularly isolated from soil profiles may lead eventually to a clearer interpretation of the ecological relation. ships of these organisms. To this end studies were initiated on the nutrition of a species of Mortierella. Although members of this genus are consistently isolated from soils, little is known of their nutrition.

A strain of Mortierella hygrophila Linn. was kindly supplied by Mrs. Turner of the Botany Department, University of Nottingham (Uni. Nott. No. 11isolated by Claussen), and a single-spore isolation was made. The subsequent culture was employed in experiments and a subculture has been deposited at the Commonwealth Mycological Institute, Kew (Herb. I.M.I. No. 50115). Cultures were maintained on potato carrot agar, and washed-spore suspensions were employed as inoculum at a concentration of 50,000 spores/flask.

The composition of the basal culture medium was : carbohydrate source, $5,000 \mathrm{mgm}$. C ; nitrogen source, 500 mgm. $\mathrm{N} ; \mathrm{K}_{2} \mathrm{HPO}_{4}, 1.0$ gm. ; $\mathrm{MgSO}_{4} .7 \mathrm{H}_{2} \mathrm{O}$, 0.5 gm.; $\mathrm{FeCl}_{3}, 0.02$ gm.; $1 \mathrm{ml}$. micro-element solution, supplying the following concentration of trace metals per litre: iron, $0.2 \mathrm{mgm}$.; zinc, 0.18 mgm. ; copper, 0.04 mgm. ; manganese, 0.02 mgm. ; molybdenum, $0.02 \mathrm{mgm}$., twice glass-distilled water to 1 l. All chemicals were 'Analar' grade and sugars were supplied by Kerfoot and B.D.H.; $p H$ initially adjusted to $6 \cdot 0-6 \cdot 5$.

Cultures were grown in 25-ml. medium in $100-\mathrm{ml}$ Erlenmeyer flasks, and mycelial felts were washed and dried overnight at $75^{\circ} \mathrm{C}$. The results were expressed as the mean weight in milligrams of five replicates.

With glucose as the source of carbohydrate the utilization of various sources of nitrogen is shown in Table 1. No growth was obtained with sodium nitrate as the source of nitrogen. However, the incorporation of 0.2 per cent yeast extract ('Difco') into the medium appeared to result in a partial utilization of the nitrate-nitrogen. Further investigation showed that the addition of small quantities of yeast extract or of peptone in a glucose medium resulted in an increase in mycelial weight above the weight due to the nitrogen content of the additions alone (Table 2).

This effect did not appear to result from a growth. factor requirement because no stimulation of growth was recorded when the following vitamins were employed singly and in combination : thiamin, riboflavine, pyridoxine, calcium pantothenate, nicotinic acid, ascorbic acid, $p$-amino-benzoic acid, biotin and

\begin{tabular}{|c|c|c|c|}
\hline \multirow[b]{2}{*}{$\begin{array}{l}\text { Nitrogen } \\
\text { source }\end{array}$} & \multicolumn{3}{|c|}{ Mycelial weight on: } \\
\hline & $\underset{\text { glucose }}{\text { Basal }}+$ & $\begin{array}{c}\text { Basal medium }+ \\
\text { glucose }+0 \cdot 2 \\
\text { per cent yeast } \\
\text { extract }\end{array}$ & $\begin{array}{c}\text { Basal medium }+ \\
\text { sucrose }+0.2 \\
\text { per cent yeast } \\
\text { extract }\end{array}$ \\
\hline $\begin{array}{l}\mathrm{NaNO}_{3} \\
\mathrm{NH}_{4} \mathrm{H}_{2} \mathrm{PO}_{4} \\
\left(\mathrm{NH}_{4}\right)_{2} \mathrm{SO}_{4} \\
\mathrm{NH}_{4} \mathrm{NO}_{3} \\
\text { Glycine } \\
\text { Peptone }\end{array}$ & $\begin{array}{r}0 \cdot 0 \\
14 \cdot 6 \\
9 \cdot 6 \\
9 \cdot 2 \\
36 \cdot 5 \\
147 \cdot 3\end{array}$ & $\begin{array}{r}102 \cdot 1 \\
75 \cdot 8 \\
65 \cdot 3 \\
81 \cdot 1 \\
115 \cdot 8 \\
141 \cdot 6\end{array}$ & $\begin{array}{r}77 \cdot 2 \\
20 \cdot 3 \\
14 \cdot 9 \\
13 \cdot 7 \\
18 \cdot 0 \\
140 \cdot 2\end{array}$ \\
\hline $\begin{array}{l}\text { Yeast extract } \\
0.2 \text { per cent }\end{array}$ & $81 \cdot 9$ & - & - \\
\hline
\end{tabular}

Table 2

\begin{tabular}{|c|c|}
\hline Source of nitrogen & $\begin{array}{l}\text { Mycelial weight on basal } \\
\text { medium }+ \text { glucose }\end{array}$ \\
\hline $\begin{array}{l}\mathrm{NaNO}_{\mathrm{s}} \\
\text { Yeast extract, } 0.2 \text { per cent } \\
\text { NaNO }_{3}+\text { yeast extract, } 0.2 \text { per cent } \\
\text { Peptone, } 0.1 \mathrm{gm} \text {. } \\
\mathrm{NaNO}_{8}+\text { peptone, } 0.1 \mathrm{gm} \text {. } \\
\text { Peptone, } 0.01 \mathrm{gm} . \\
\mathrm{NaNO}_{3}+\text { peptone, } 0.01 \mathrm{gm} .\end{array}$ & $\begin{array}{r}0 \cdot 0 \\
88 \cdot 2 \\
161 \cdot 7 \\
62 \cdot 7 \\
94 \cdot 9 \\
6 \cdot 4 \\
23 \cdot 0\end{array}$ \\
\hline
\end{tabular}

inositol. No growth response was noted when yeast extract was ashed and added to a sucrose-nitrate medium. Various amino-acids were added to a glucose-nitrate medium at a concentration of 0.016 gm. acid per cent. Some growth resulted with almost all, the relative growth-rates being: $\mathrm{L}$-arginine, DLalanine, > DL-ornithine, L-glutamic, aspartic acid, asparagine, glycine, L-cystine, L-tyrosine, $>$ DLthreonine, L-histidine, $>$ DL-phenyl alanine, DLvaline, DL-methionine, DL-norleucine, and none on DL-tryptophan. At best, growth was not as good as with peptone. Apparently there was no indispensable amino-acid.

The replacement of glucose with sucrose in the basal medium plus yeast extract provided a similar pattern of nitrogen utilization (Table 1 ).

In order to utilize nitrate-nitrogen, $M$. hygrophila may require a source of preformed nitrogen compounds to provide sufficient onergy for the production of an adaptive nitrate reductase enzyme. This explanation appears to be only partially true because with decreas ing peptone additions mycelial weights also decrease.

The availability of various sources of carbohydrate to $M$. hygrophila was determined on a medium containing sodium nitrate and $0 \cdot 2$ per cent yeast extract. The results are shown in Table 3.

\begin{tabular}{|c|c|}
\hline Carbohydrate source & $\begin{array}{l}\text { Mycelial weight on basal medium }+ \\
\text { NaNO }_{8}+0 \cdot 2 \text { per cent yeast extract }\end{array}$ \\
\hline $\begin{array}{l}\text { Glucose } \\
\text { Maltose } \\
\text { Raffinose } \\
\text { Lactose } \\
\text { Sucrose } \\
\text { Arabinose } \\
\text { Starch } \\
\text { Glycogen }\end{array}$ & $\begin{array}{r}106 \cdot 9 \\
87 \cdot 2 \\
25 \cdot 3 \\
24 \cdot 5 \\
20 \cdot 9 \\
17 \cdot 5 \\
32 \cdot 6 \\
20 \cdot 2\end{array}$ \\
\hline
\end{tabular}

Macerated, washed Whatman No. 50 filter paper was added to the basal medium containing sodium nitrate and yeast extract to test for possible cellulolytic activity. $M$. hygrophila was not able to grow on this medium, even when 0.05 per cent 'starter' glucose was added.

This work was carried out during the tenure of a research fellowship in the University of Nottingham.

Soil Bureau, R. H. ThorNTON

Wellington, New Zealand. 